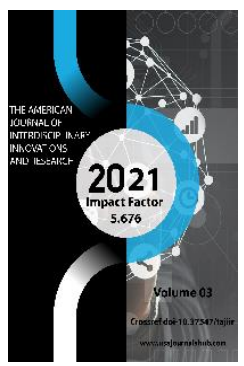

\section{Typological Features Of Traditional Settlements In Fergana}

\author{
S. A. Qodirova \\ Associate Professor Tashkent Institute of Architecture and Civil Engineering, Uzbekistan \\ L. Sh. Raximov \\ Assistant Tashkent Institute of Architecture and Civil Engineering, Uzbekistan \\ R. X. Qurbonov \\ Assistant Tashkent Institute of Architecture and Civil Engineering, Uzbekistan \\ A. B. Djoldasov \\ Assistant Tashkent Institute of Architecture and Civil Engineering, Uzbekistan
}

Copyright: Original content from this work may be used under the terms of the creative commons attributes 4.0 licence.

\title{
ABSTRACT
}

This article is intended to be used in the design of the Fergana traditional housing project. In solving the architectural and structural part, the formation of the functional basis of the rooms. Full demonstration and implementation of the functional spatial solution of the main rooms.

\section{KEYWORDS}

Civilization, tobadon, environment, hole, functional basis, functional zones.

\section{INTRODUCTION}

The Fergana Valley is bounded on the south and north by mountain ranges, on the west it joins the plains of Central Asia, and on the east it is connected with Kashgar by the TerakDovan pass. Natural resources and cultural ties have made a significant contribution to the development of the cultural center here. In ancient times, the Fergana Valley was connected for some time to a large caravan route from China, which supplied silk even to the Roman Empire. Local culture was influenced by Chinese civilization. Particular attention is paid to connecting the places of Central Asian architecture with the natural climatic conditions, colorful landscape, clear, bright sky. For this purpose, the terraces 
connecting the room with nature, decorative patterns that mimic the natural landscape, as well as tobadan, hole, windows, which provide light in the room, were widely used. walls of the houses with a thickness of 60-70 $\mathrm{cm}$ are common, and all four walls are thick. Fergana is one of the regions with the highest seismicity.
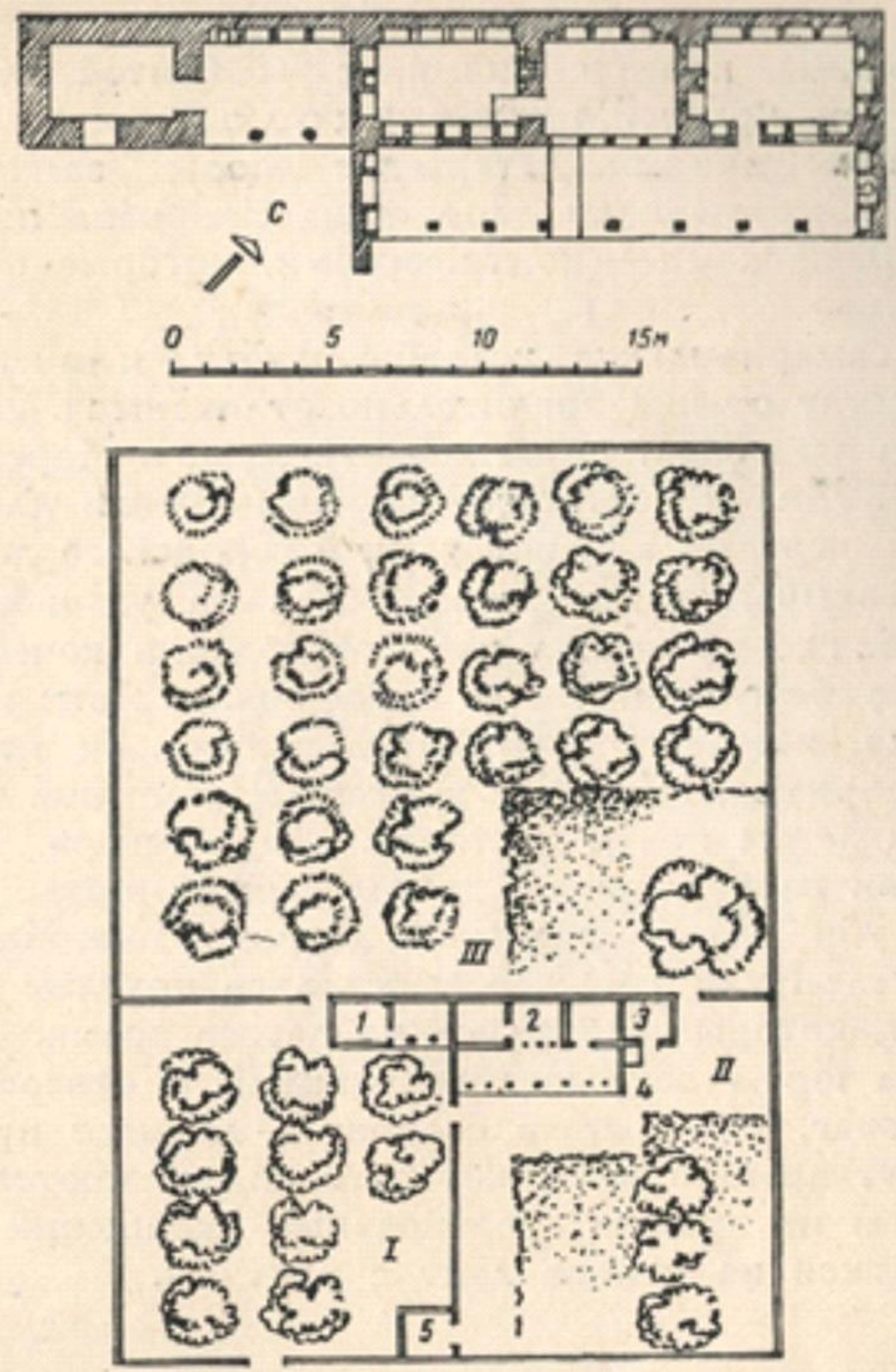

The Fergana residential building is the strongest in terms of construction, and the 
Picture 1. Dadaboev Tuychiboy's house, Fergana. I-outside. II - internal. III - fruit of the garden. 1 hotel. 2nd living room. 3-warehouse. 4 chickens. 5-barn.

In Namangan, where the seismic risk is high, the walls of the apartment building are up to $90 \mathrm{~cm}$ thick. Strong walls are also needed to lift the heavy roof. The structure of the porch is very important in the appearance of the house. Terraces depend to some extent on the strength and direction of the wind, the orientation of the house, etc. In the Fergana Valley, terraces are built in front of houses facing more south, which protects the house from overheating in summer and insulates the house in winter. The following features can be highlighted here:

1) Dwelling rooms facing south and protected by a veranda;

2) There is a winter porch (the Kashgar porch) protected by curtains;

3) The entrance to the rooms lies on the porch;

4) The windows are protected by a wooden curtain in winter;

5) There is a stove in the house, it serves to cook and heats the house.

The architecture of the house also depends on the customs and traditions of the people and the national culture. In the Fergana Valley, a unique way to plan a house is to have a covered porch (the Kashgar porch), from which you can move from room to room. The central room will be spacious and will serve not only as a front room, but also as a common living room. The dwelling rooms were mostly built facing the south, southeast and east. Housing around the perimeter of the yard is less common than in other oases. Inside the room, all the walls are covered with shelves, between which are placed smooth panels. Shelves can be divided into cells of different sizes. These shelves are decorated with various patterns and pictures of plants (fruits and flowers). The distinctive features of the facade are the raised window curtains (shutters), the bars on the top of the door and the barred walls. Ganch carvings are widely used to decorate the walls (mostly in Kokand).

Compositional features of Fergana houses

One of the most widespread features of the architecture of the Fergana house is its art and space. The size and layout of the place of residence is closely related to the vital needs of the family. The house is like a living organism, and as the number of family members' increases, some buildings will be demolished and others will be built. Thus, a common place is a set formed over a long period of time, which prevents the consistent implementation of any idea of the plan or composition. In the conditions of intensive development of city centers, due to the chaotic configuration and narrow courtyards, it was often impossible to implement the plan correctly. However, it should be noted that in such conditions, the builders managed not only to use every meter of space wisely, but also not to damage the overall artistic impression. The principle of symmetry is not seen in any place. The composition of the Fergana house with the central porch is completely asymmetric. The importance of the central porch as a compositional center is often emphasized by the fact that the roof of the open porch is correspondingly high. In 
Fergana houses, access to the veranda was preferred through the side corridor, as a central pillar was placed in the middle of the veranda. One of the main features of the residential composition of folk architecture of Uzbekistan is the spacious environment.

Picture 2. The inner porch (Kokand), 1873.

By spaciousness, we understand the existence of closed elements in architecture that the local population takes place in the open air or on the open porch, and in order to keep

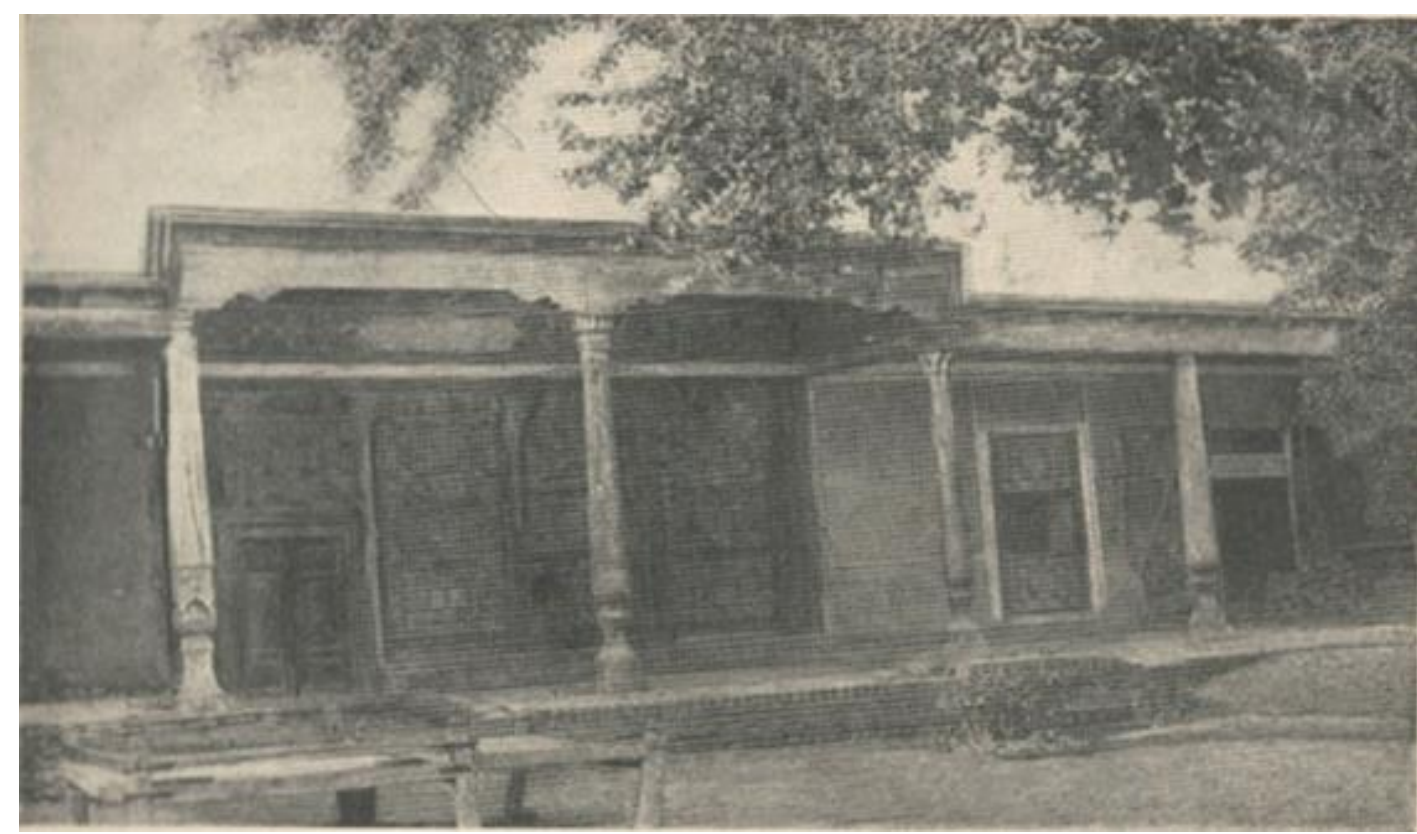

connect the main part of the building to the external environment - closed porches (loggias), columns, and platforms.

In residential architecture, as in other countries with hot climates, the environment has its own functional basis: most of the life of from the heat, only the roof is required. In a residential building in Fergana, the idea of space is constantly being developed, and the closed area of the rooms is connected with the Kashgar porch, which leads to the open porch gallery. 


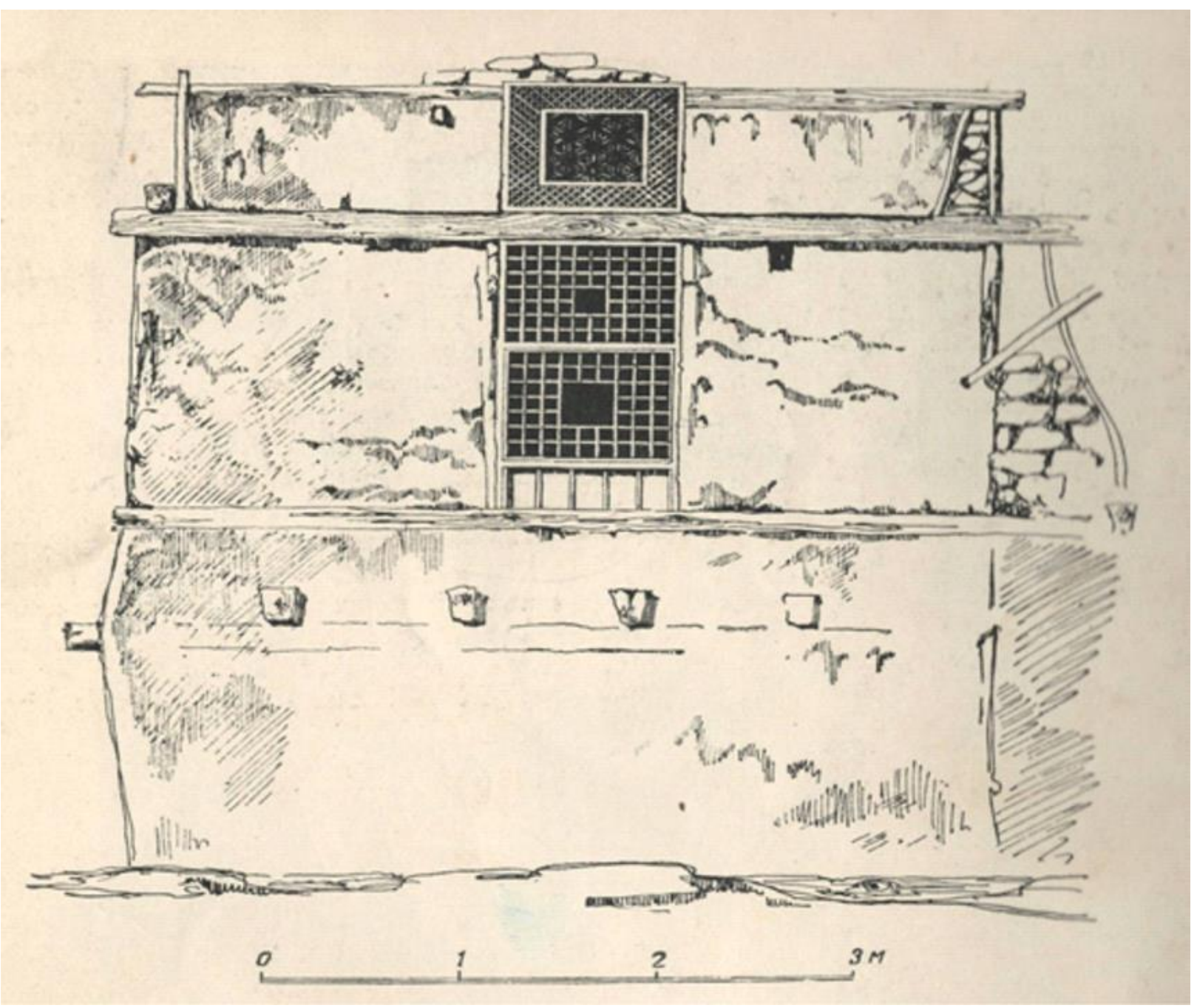

Picture 3. Exterior of the building (Kokand)

The walls of the room are mostly made of tin, and there are shelves and holes in it. Doors and windows are installed in the facade of the house facing the yard. The windows are closed with wooden curtains, and the upper part of the doors and windows are decorated with embossed bars. These bars are called tobadon. The porch of the Fergana house consists of pillars and is located in front of the living quarters. In the 1920s, the art of applied construction rose to a qualitatively new level.
The traditional construction techniques have been enriched and given a new dimension. Basically, the symmetrical Fergana houses (consisting of two rooms and a veranda) represent a full-fledged volume with a minimal structure, therefore, as the volume increases, it changes its architectural features: facades facing south and east, an additional corner room and interior porches or the area of the half-open Kashgar porch will be doubled, but the porch will remain only on the south side. 
The porches built over the entrance gate in the Kokand houses are noteworthy. They are elegantly designed grilles, charming with the
The example shown here differs in the completeness and proportionality of the individual parts (Figure 4).

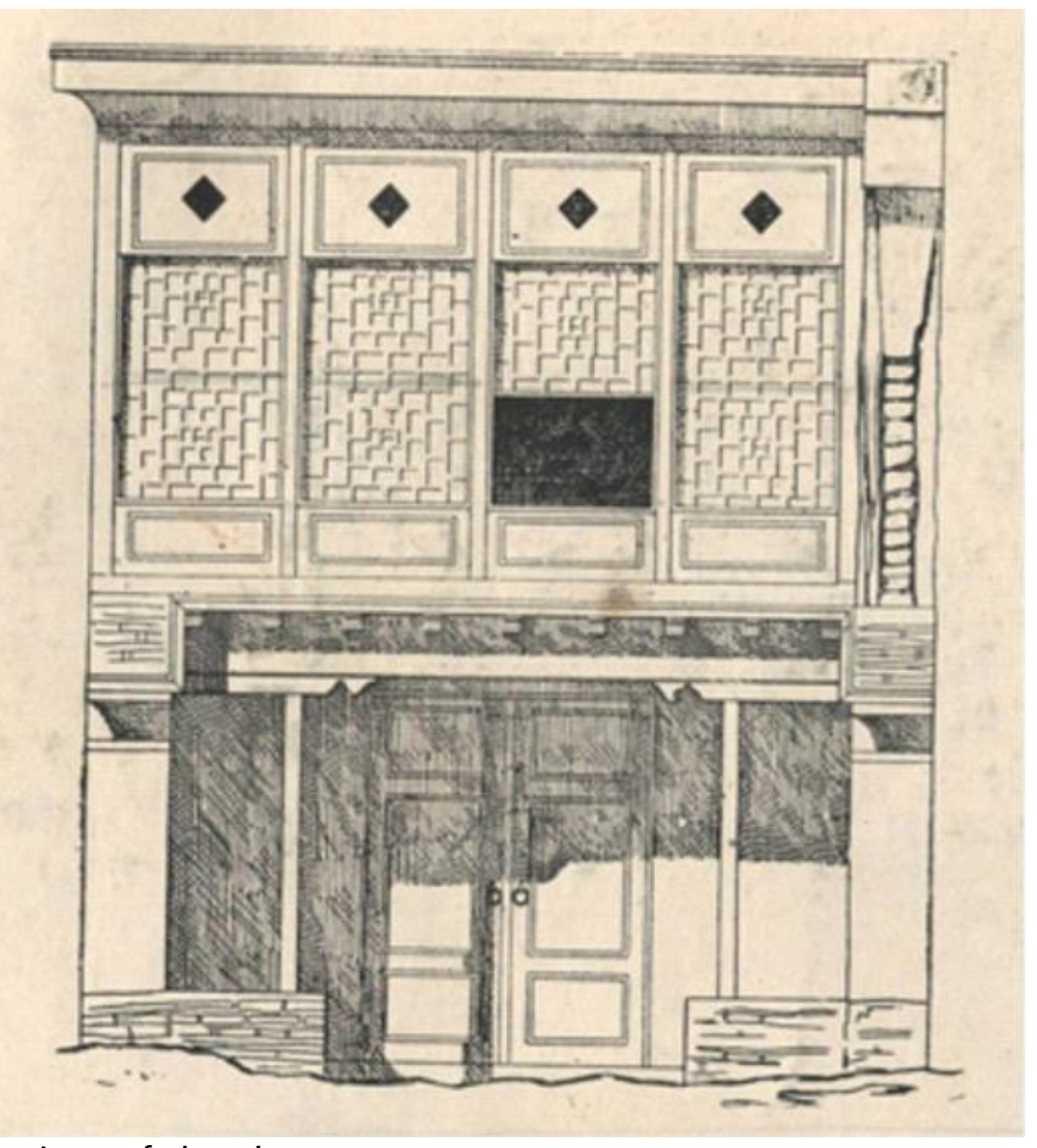

flatness of the proportions of the elements.

Picture 4. House with a loggia (Kokand)

The Margilan model of the closed courtyard is interesting in terms of the appearance of the winter Kashgar porch. The façade of the house has wooden bars, the ceiling pillars rest on four poles, and the light falls through a hole (Fig. 5). The doors of the living rooms do not lead to the courtyard, but to the closed veranda. 
The American Journal of Interdisciplinary Innovations and Research (ISSN-2642-7478)

Published: January 30, 2021 | Pages: 48-58

Doi: https://doi.org/10.37547/tajiir/Volume03Issue01-09

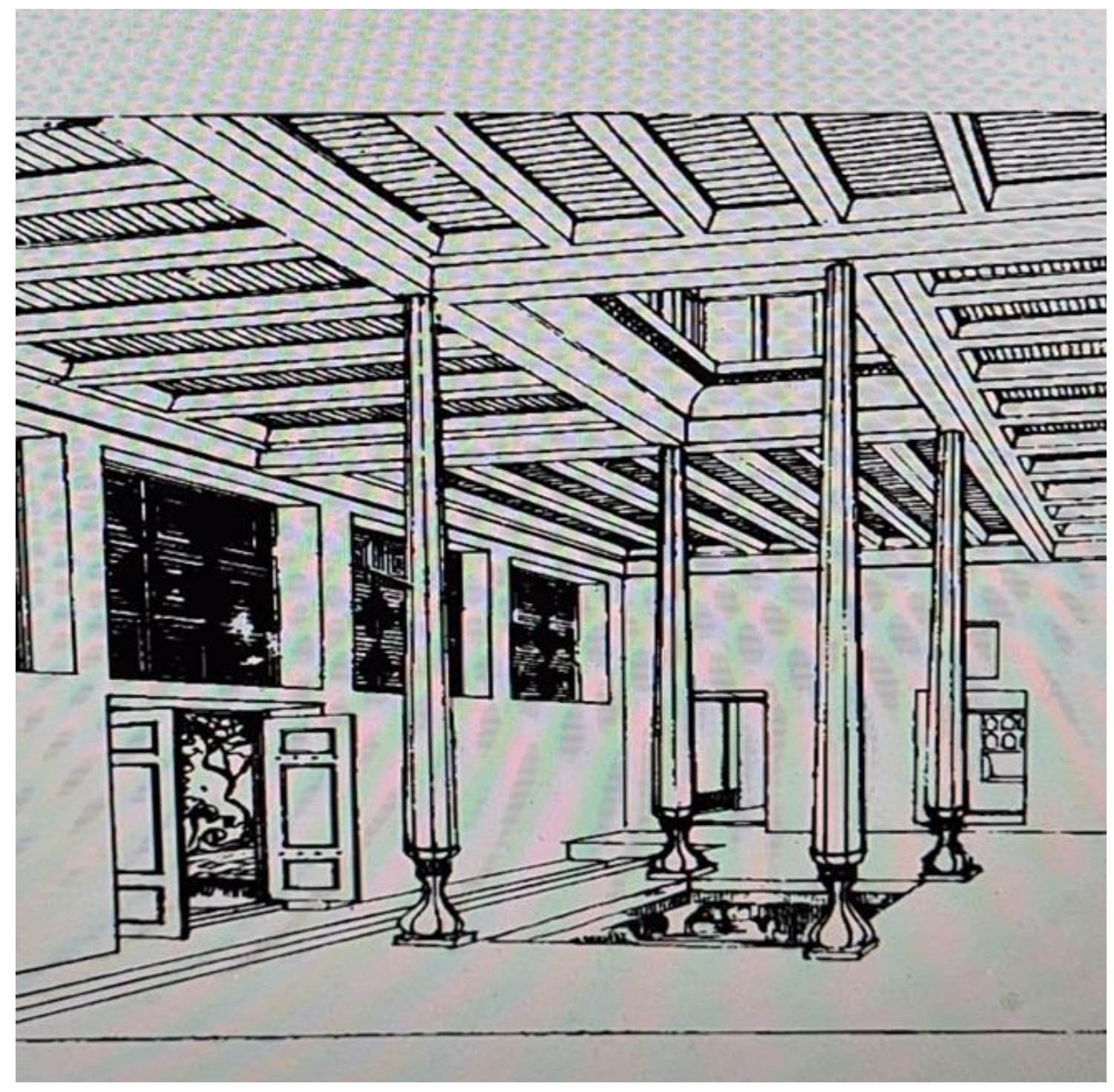

Picture 5. Interior of the Kashgar porch in Margilan.

The interaction of architecture and nature (including relief) should be considered separately. Water is of great importance for the arid climate of Central Asia. If there is a garden in the yard of the house, of course, there will be a pool surrounded by trees. Greenery is the second lifeblood of a brutally hot climate. A vine was planted in the yard, and three goals were achieved at the same time: harvesting grapes, protecting the yard from the sun, and decorating the house. The vine has wonderful decorative properties, which are used very skillfully. The vines are mainly planted in the front of the house and used as an umbrella in the vineyard. 


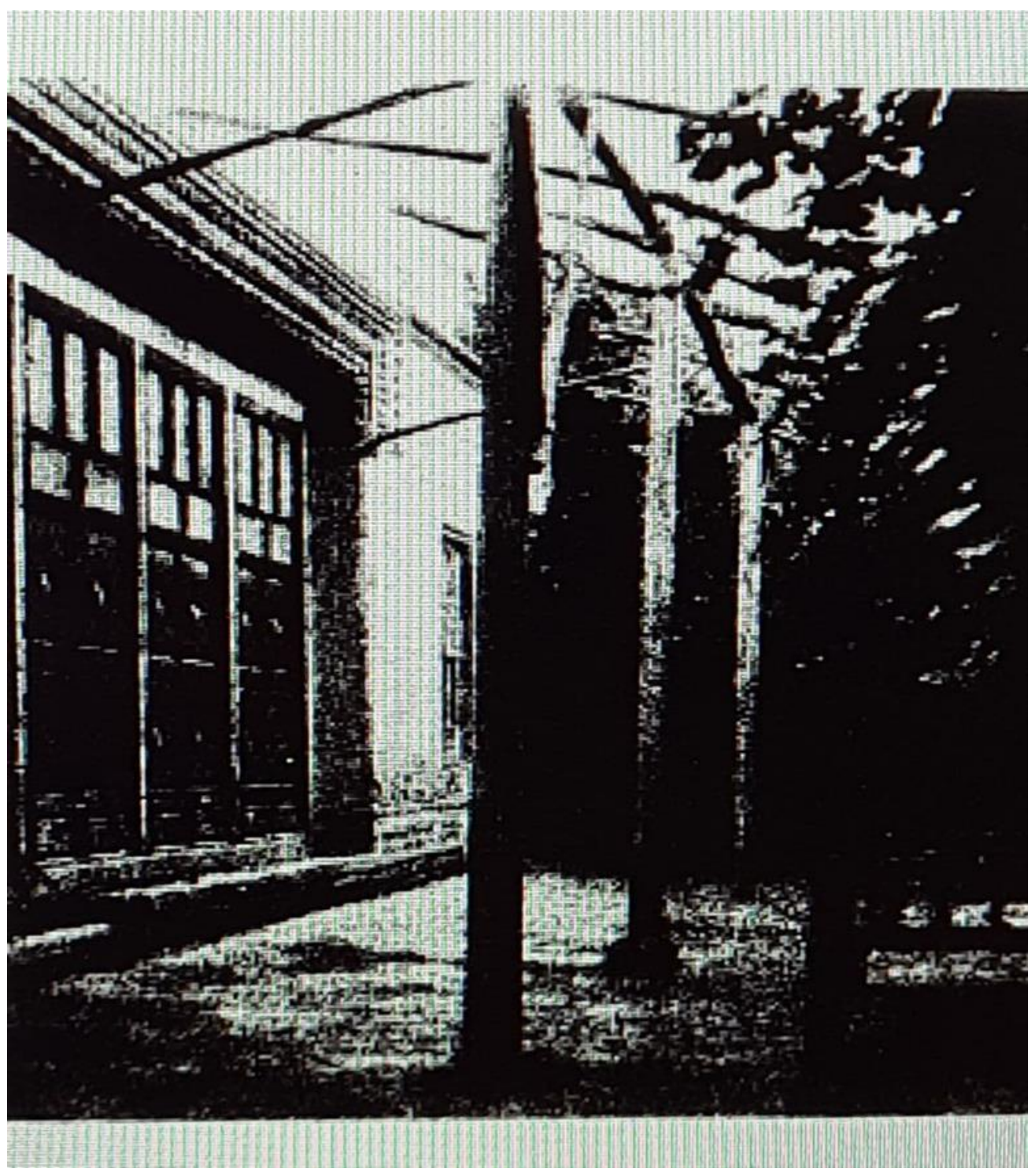

Figure 6. View of the courtyard in Namangan.

In Margilan, the canopy of the vineyard was made horizontally, 3-4 m above the ground and attached to the porch or roof of the house. In Namangan, the umbrella of the vineyard is made in the shape of a triangle (Fig. 36). According to the population, this way the air circulation under the green umbrella will be better. The Kokand style is unique and effective. Here the lattices rise to the top, and the roof of the house forms an open veranda with green leaves. It has not only decorative, but also well-known practical purposes, as the grapes ripen better under a heated roof in the sun. 


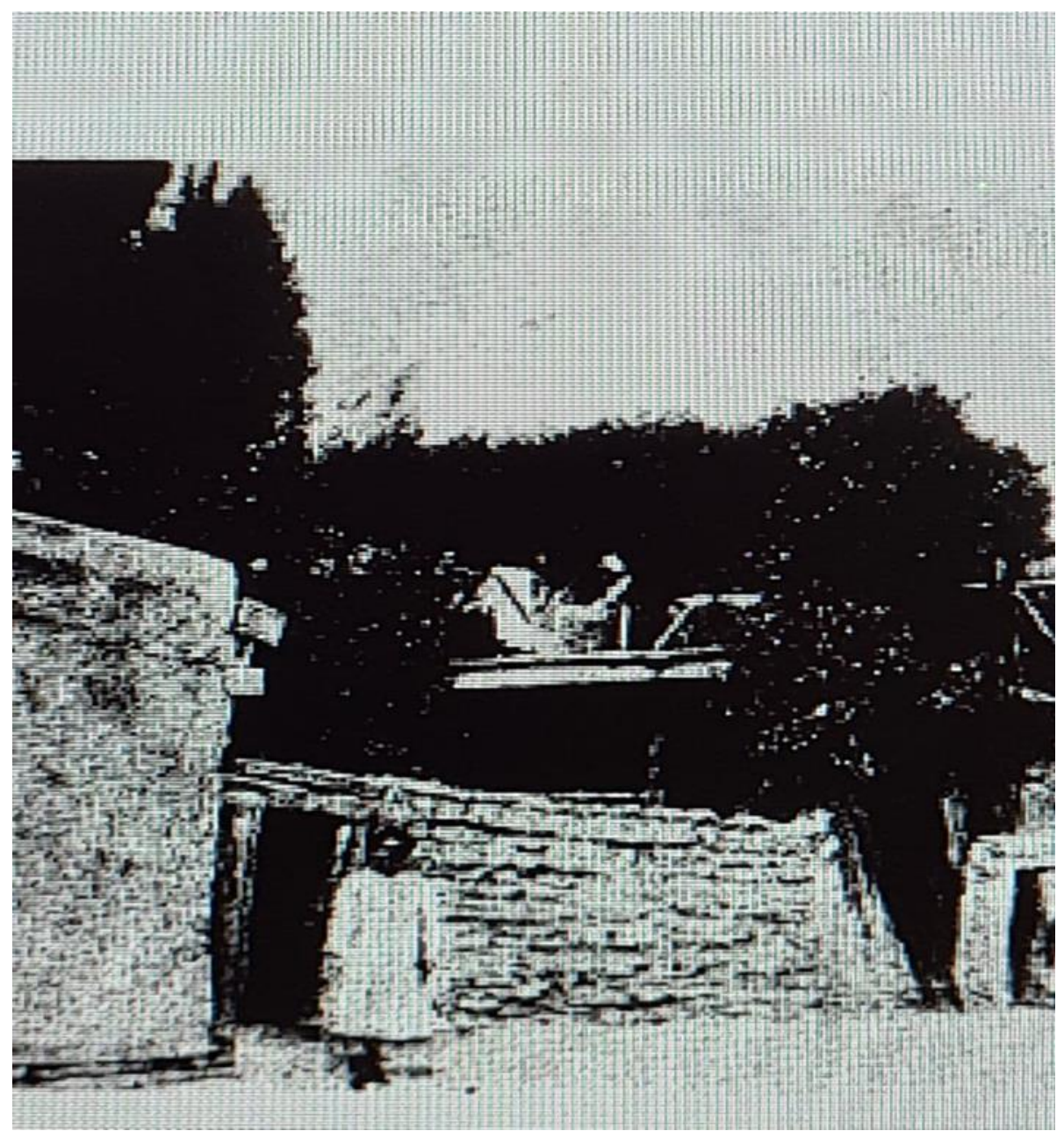

Picture 7. Vineyard on top of Kokand house.

It can be concluded that the structure of the Uzbek house is based on a deep understanding of the high foundations of architecture. The composition and constructions of the dwelling were built on the basis of simple building materials at hand, but the architectural idea was at a high level.
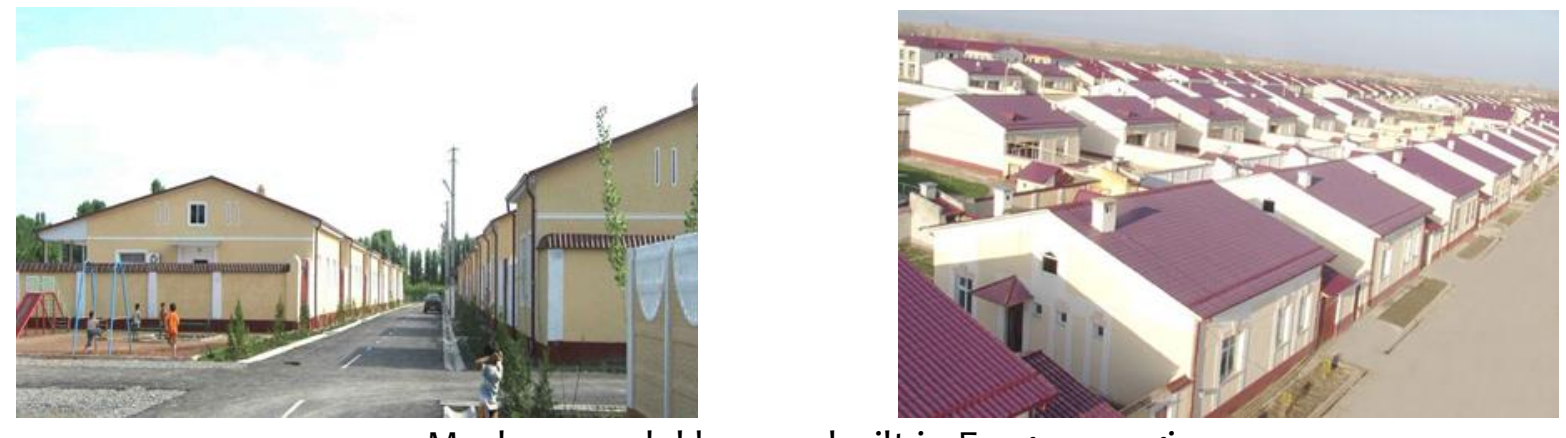

Modern model houses built in Fergana region. 


\section{Picture 8}

Picture 9

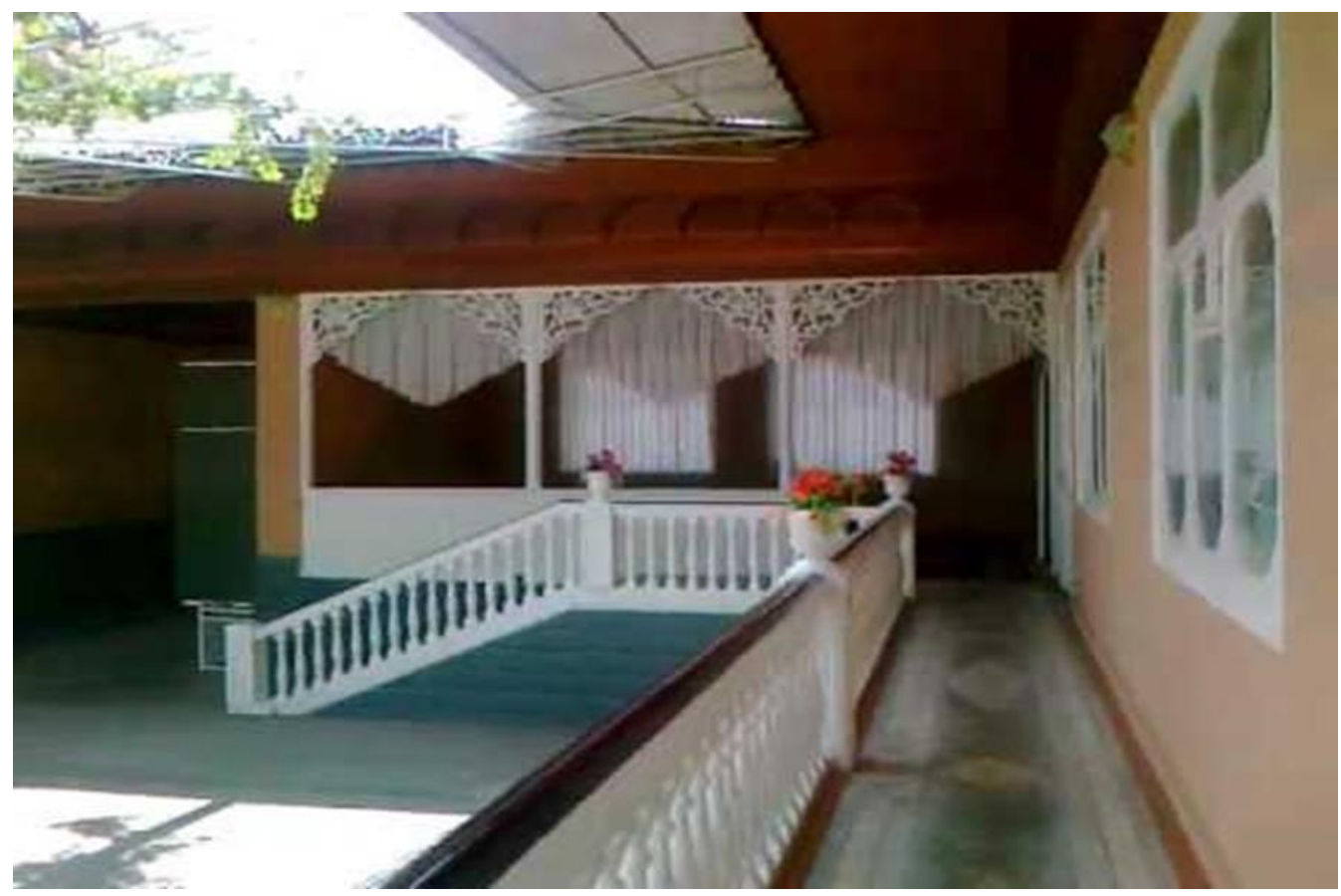

Picture 10

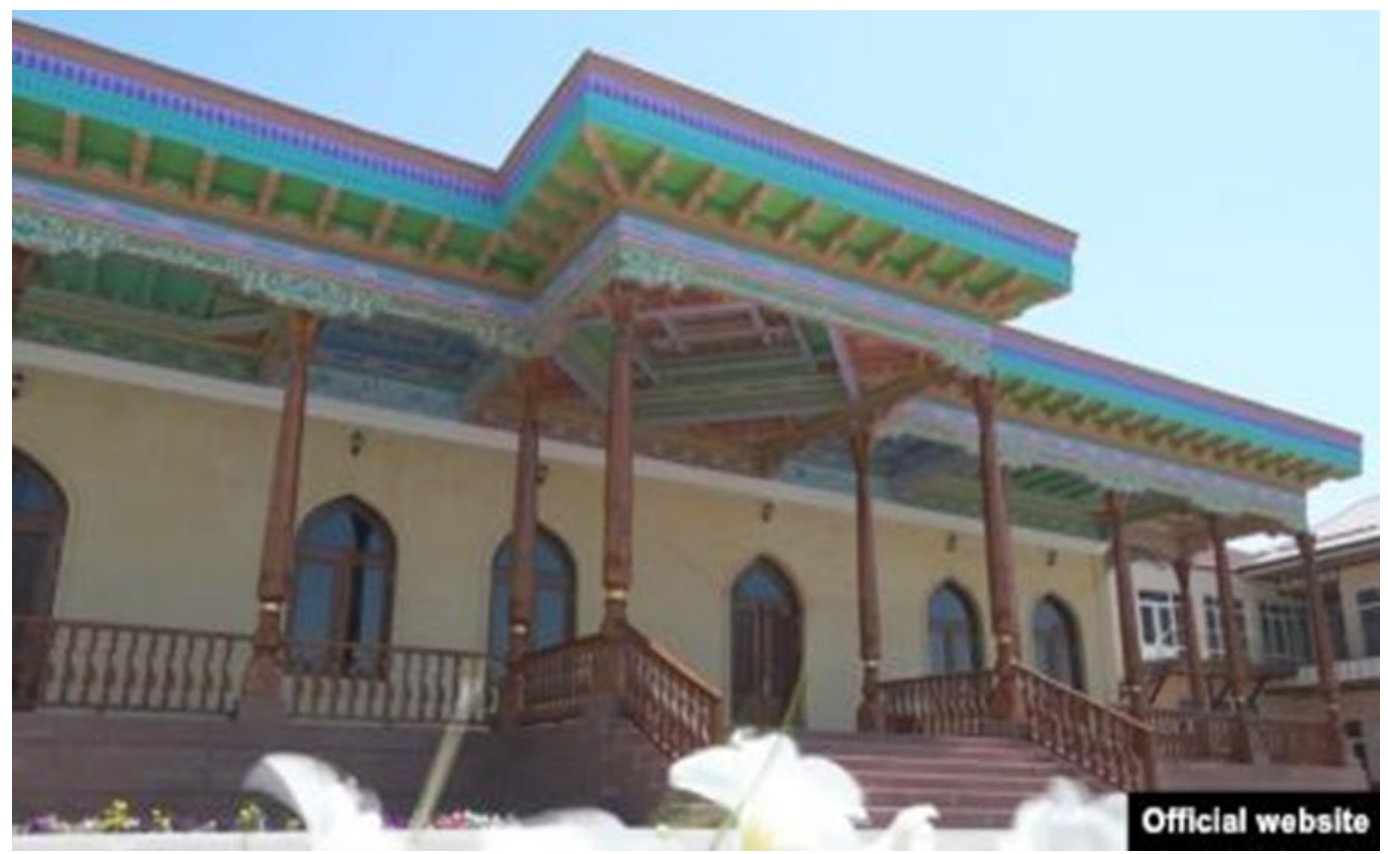

Picture 11 


\section{REFERENCES}

1. Nozilov D.A. "Interior in Central Asian architecture." Science. Tashkent: 2005.

2. Zoxidov P.Sh. "The world of the architect”. Tashkent: 1996.
3. Mankovskaya L.Yu. "Typological foundations of architecture of Central Asia" (IX-XX) Tashkent: 1980.

4. Voronina.V.L. " Folk traditions of architecture of Uzbekistan." Moscow: 1971

5. General history of architecture, vol. 8, Moscow:1969 